\title{
Exploring Social Business Pathways: Green Map System as a Case in Point
}

\author{
Explorando Trilhas de Negócios Sociais: O Green Map System como Exemplo \\ Característico
}

Balashankar Mulloth ${ }^{1}$ (

\section{ABSTRACT}

Objective: social entrepreneurship holds promise as a way for organizations to create value for both individuals and communities. The objective of this paper is to observe and analyze the ways Green Map System, a not-forprofit social venture, supports sustainable community development and local leadership by sharing tools, icons, and technology for mapping ecosites around the world. The role of technology and digital networks, as well as the impact of global linkages, is also observed and emphasized. Methods: the research approach used for this paper is qualitative in nature and uses the case study methodology. Evidence was based on data collection methods, such as archived documents, interviews, questionnaires, and direct observations at formal and informal settings. Results: using the example of Green Map System, I demonstrate that creating local partnerships, as well as including and collaborating with a wide range of stakeholders, is key to fulfilling the organization's mission-driven vision. Conclusions: I use the example of Green Map System and describe how the organization went about creating social and business pathways by outlining the growth, evolution, and social innovation of the organization. I also layout the challenges and decision dilemmas the organization faces as it continues to grow as a social business.

Keywords: social enterprise; social business; Green Map System; community development.

\section{RESUMO}

Objetivo: o empreendedorismo social se mostra promissor como forma de as organizaçóes agregarem valor tanto para os indivíduos quanto para as comunidades. $\mathrm{O}$ objetivo deste trabalho é observar e analisar as formas como o Green Map System, um empreendimento social sem fins lucrativos, apoia, de forma sustentável, o desenvolvimento da comunidade e a liderança local mediante o compartilhamento de ferramentas, ícones e tecnologia com vistas ao mapeamento de sítios ecológicos em todo o mundo. Observa-se e enfatiza-se o papel da tecnologia e das redes sociais, bem o impacto das articulaçóes globais. Métodos: esta pesquisa tem abordagem de natureza qualitativa e emprega a metodologia de estudo de caso. As evidências se baseiam em métodos de coletas de dados que incluem documentos de arquivos, entrevistas, questionários e observaçôes diretas em contextos formais e informais. Resultados: usando o exemplo do Green Map System, demonstra-se que a criaçáo de parcerias locais e a promoçáo da inclusão e colaboraçáo de uma ampla de stakeholders são essenciais para o cumprimento da sua visão direcionada pela missão. Conclusóes: utilizase o exemplo do Green Map System e, a partir do crescimento, evoluçáo e inovação social dessa organizaçáo, descreve-se como ela trilhou caminhos sociais e de negócio. Também se apontam os desafios e dilemas decisórios enfrentados pela empresa à medida que cresce enquanto um negócio social.

Palavras-chave: empresa social; negócio social; Green Map System; desenvolvimento comunitário.

\begin{tabular}{|c|c|c|c|c|c|c|c|c|}
\hline 1 & 2 & 3 & 4 & 5 & 6 & 7 & 8 & 9 \\
\hline$\stackrel{D}{2}$ & $\stackrel{8}{2}$ & $x$ & & & & & & \\
\hline (x) & 2 & & & & & & & \\
\hline (x) & 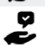 & & & & & & & \\
\hline
\end{tabular}




\section{INTRODUCTION}

Maps are graphic representations of our inner and outer worlds (Lydon, 2003). Early humans developed mental maps as they developed language and spatial consciousness. In both oral and written traditions, they named symbols, place names, individuals, and actions. Maps are seen as powerful navigation tools that can help guide our way in the world (Makower, 1992). Community mapping is a graphic learning, development, and planning tool that connects people to one another and their home places. Community maps are the collective representations of geography and landscape, and community mapping is the process to create such representations.

The past year has brought some incredible maps, illustrating issues such as how the Earth's carbon cycle works, which then unveiled new understanding about how carbon emissions from one country affect other parts of the planet; or how wilderness is disappearing, which pointed out some surprising conclusions about how little space humans actually inhabit while still impacting massive amounts of the globe (Mulloth, 2011). Maps are being increasingly used as a tool to highlight and visually represent critical issues such as the effects of climate change across the globe via geographic representations of rising sea levels, melting glaciers, draughts, etc. Having local information such as rainfall level, distribution of wildlife, or demographic data integrated within the map allows more efficient analysis and better decision-making. As of the last quarter of the 20 th century, the functionality of maps has been greatly advanced by technology, simplifying the superimposition of spatially located variables onto existing geographical maps.

An important player in the mapping industry is Google Maps. Google Maps (for a time named Google Local) is a basic web mapping service application and technology provided by Google, free (for non-commercial use), that powers many map-based services, including the Google Maps website. According to one of its creators, Lars Rasmussen, Google Maps is "a way of organizing the world's information geographically." In the recent past, Google has created the Google Maps API to allow developers to integrate Google Maps into their websites with their own data points as a free service. Programmers around the world have created new applications using the code behind Google's map service. They mix Google Maps' API (application programming interface) with other data. These new sites let you specify points such as free Wi-Fi hotspots in New York City as an example. Thus, the industry seems to have evolved from a static, two-dimensional representation of geographic areas to a dynamic, interactive, and three-dimensional view, which can be used to promote sustainability and community participation. As an iterative process that builds capacity and skills, it can also help give familiar places a fresh perspective and act as a guide to promote ongoing greening efforts in communities around the globe. Innovation nowadays is constructed as occurring within increasingly network-like, fluid, and interlinked structures. Analogous to Google Maps, Green Map System uses their Open Green Map (OGM) platform to bring together thousands of local green mapmakers in 65 countries who are producing powerful maps and projects using their award-winning icons and tools.

Innovation as a whole is described to be increasingly concerned with the overall ecosystem (Adner, 2006), where the complexity of decision-making draws even more on the usability of a network of relationships and organizations, due, in part, to conceptualizations of the 'strength of weak ties' (Granovetter, 1973; 1983). Much of technological innovation is construed as 'democratized' by how it is made 'open,' recently described as populated with numerous flexible 'creation nets' rather than traditional stand-alone or formally linked firms (Chesbrough, 2003; Hagel \& Brown, 2008; Von Hippel, 2006). This is illustrated in a unique form of community mapping, the Green Map ${ }^{\oplus}$ System case study below. In such a setting, social entrepreneurship may well flourish, continuously adapting to changes and opportunities of these social logics of emergent becoming. For civil society actors, social entrepreneurship may represent a driver of systemic social change (Nicholls, 2006), a space for new hybrid partnerships (Austin, Stevenson, \& Wei-Skillern, 2006), or a model of political transformation and empowerment (Alvord, Brown, \& Letts, 2004).

Stating the three traditional markers of community, (a) shared consciousness, (b) rituals and traditions, and (c) a sense of moral responsibility, Muniz and O'Guin (2001) offer the following definition: Social entrepreneurship is operationalized as a critical process management observed from the environmental actions and sensitivities perspective. Social entrepreneurs bring the invisibles of the systems to the central point of attention and introduce more sustainable and participatory approaches (Seelos \& Mair, 2005). They change the way systems function while dealing with the solutions that inevitably serve to change the world. Advocates of social entrepreneurship have long argued that this social logic of community building should be considered by governments as a key mechanism to enable local economic development and sustainable development initiatives (Horwitch \& Mulloth, 2010). This often involves other forms of organization than limited companies, pursued as collective accomplishments not easily affiliated with an individual entrepreneur (Vasi \& King, 2012). This movement toward collective social innovation and co-creation via entrepreneurship is testament of how the private economic sphere and the public social sphere merge (Shaw \& Bruin, 2013), to provide us with a new typology 
of 'social security.' In fact, the role of entrepreneurship in encouraging public-private partnerships that in turn create new forms of social security within societies is an interesting recent trend (MacGregor \& Carleton, 2011).

The objective of this paper is to observe and analyze the ways Green Map System, a not-for-profit social venture, supports sustainable community development and local leadership by sharing tools, icons, and technology for mapping eco-sites around the world. The role of technology and digital networks, as well as the impact of global linkages, will be also observed and emphasized. I organize the paper as follows. I start with an introduction to literature on social innovation and social entrepreneurship. Then I present the ethnographic method. Thereafter follows the detailed Green Map System case study highlighting the organizations social goals, achievements, and business agendas. To end, I present a discussion section that highlights how Green Map Systems went about creating social and business pathways along with some of the challenges they encountered, and proposed steps for future research.

\section{LITERATURE OVERVIEW}

Early on, Catford (1998) defined social entrepreneurs as individuals who are "at the heart of community-based initiatives, finding innovative solutions to problems that face the most impoverished and marginalized communities." The creation of social value underpins social entrepreneurship, in tandem with conceptualizations of the social entrepreneur (Choi \& Majumdar, 2014). They see through that 'sensible ideas take root and actually change people's thinking and behavior across a society' (Bornstein, 2007). The social entrepreneur is characterized as 'compassionate' and this is believed to stimulate 'agency' (Grimes, McMullen, Vogus, \& Miller, 2013). Social entrepreneurship is a form of entrepreneurship that is proposed to better spur development (Seelos \& Mair, 2005) in the form of poverty alleviation (Khavul \& Bruton, 2013) and sustainability (Dean \& McMullen, 2007; Kuckertz \& Wagner, 2010; Nicholls, 2006). Social entrepreneurship is thus primarily concerned with explicitly aspiring to solve a major societal problem with professional management and business efforts and, indeed, enable the creation of widespread social change (Drayton, 2010). Social entrepreneurship has moreover been correlated with positive change in municipalities (Beveridge \& Guy, 2005; Korosec \& Berman, 2006), which exemplify the interest in cross-sector collaborations that likewise may be profitable (Seelos \& Mair, 2005). Social entrepreneurship is thus assessed in relation to what impact and influence it has in terms of social impact, innovations, and outcomes, and not simply in terms of size, growth, or processes (Choi \& Gray, 2008; Zahra, Gedajlovic, Neubaum, \& Shulman, 2009). It can be argued that increasingly, non-governmental organizations, non-profit organizations (NPOs), entrepreneurial firms, governments, and public agencies are collaborating strategically on social entrepreneurship.

Different schools have defined entrepreneurship through different perspectives using diverse dimensions. One of the rare approaches on which there is an allover compromise is defining it as a process (Bygrave, 1989) based on its observable operational steps, as entrepreneurs are doers and as this is the basic distinction of an entrepreneur from a capitalist. Social entrepreneurship is accordingly regarded as an entrepreneurial process management with its diversifying characteristics revolving around the social responsibility. Social entrepreneurs have to follow the same commercialization steps and develop an appropriate market behavior targeting the socially sensitive forerunners in the first place, with and for the stakeholders of the social cure he/she is proposing. In their proposal of a typology of social entrepreneurship, Zahra, Gedajlovic, Neubaum and Shulman (2009) maintain that social entrepreneurship emerges in small, medium, and large scale. From the Hayekian social bricoleur, who perceives and acts upon opportunities to address local social needs, to the Kirznerian social constructionist, who builds and operates alternative structures that address social unmet needs, to the Schumpeterian social engineer who creates newer and more effective social systems.

Further, it can be stated that what distinguishes social entrepreneurs, in individual or more collective notions, is that they see their job as changing the overall patterns and systems of society. To this extent, unlike conventional entrepreneurs, social entrepreneurs rarely allow the external environment to determine whether they will launch an enterprise. Social entrepreneurship has been propositioned to occur either 'through' existing institutions or in the 'absence' of existing institutional arrangements. When social entrepreneurship happens 'through' existing institutions, scholars look at how institutions facilitate and create boundaries of practice for social ventures (Lasprogata \& Cotten, 2003). Social entrepreneurship often takes place at the intersection of multiple institutions and may be influenced concurrently by the government, the market, and the community (Shaw \& Carter, 2007). When social entrepreneurship happens in the 'absence' of existing institutional arrangements, the creation of a venture may in itself cause a change in that existing institutional arrangement (Mair \& Marti, 2006). For example, environmental degradation may be seen as the result of failed (or absent) market mechanisms that include environmental protection.

The underlying drive for social entrepreneurship is the creation of social value as opposed to personal or shareholder wealth (Noruzi, Westover, \& Rahimi, 2010; Thake \& Zadek, 1997) and the activity of such social 
creation is characterized by pattern-breaking change or innovation (Munshi, 2010; Noruzi et al., 2010), through the creation of new combinations of, for example, products, services, organization, or production (Defourny \& Nyssens, 2010). Hart and Milstein (2003) suggest corporations can generate "sustainable value" by employing "strategies and practices that contribute to a more sustainable world and simultaneously drive shareholder value." (Hart \& Milstein, 2003, p. 57). Porter and Kramer (2011) go on to advocate the concept of 'shared value creation' as a means by which organizations and companies can pursue their social responsibility agendas. The definition most often cited is that of Phills, Deiglmeier and Miller (2008): "a novel solution to a social problem that is more effective, efficient, or just than existing solutions and for which the value created accrues primarily to society as a whole rather than private individuals." (Phills, Deiglmeier, \& Miller, 2008 , p. 3). Unlike business innovations, which are driven by market and consumer needs, social innovations have a cultural focus, aspiring to address unmet human and social needs (Lettice \& Parekh, 2010).

\section{METHODOLOGY}

The research approach used for this paper is qualitative in nature and is based on a combination of interpretative interviews and direct observations (Burrell \& Morgan, 1979; Eisenhardt, 1989; Gioia \& Pitre, 1990). Following the work of other scholars (Amabile et al., 2001; LeonardBarton, 1990), I carried out the research in close interaction with practitioners who deal closely with the organization of study (Shah \& Corley, 2006). Specifically, the research is designed to follow the development of Green Map System, over time and in different locations.

As with most qualitative case study research, this study combines different data collection methods, such as archived research documents, interviews, questionnaires, and direct observations at formal and informal settings (Eisenhardt, 1989). I conducted over fifteen interviews with Green Map System's Founding Director and a range of key stakeholders including board members, office managers, and clients over a two-year period. These included personal and telephone interviews, and brief questionnaires administered over email. Additionally, I performed extensive primary and secondary historical research and analysis. I accessed primary and secondary archival sources such as news reports and industry reports issued, as well as social media coverage.

In the case of inductive approach, two main options are available to the researchers: (a) exploration of the relations through existing/newly-defined phenomenon (pattern matching); (b) modeling the development path of a phenomenon considering time. In both cases, different construction methods can be used. I am using the with-in case method (Eisenhardt, 1989) accordingly, which is one of the strongest qualitative methods to shed light on the yet invisible/uncovered patterns within a phenomenon. A single case is analyzed and the concrete unique patterns and phases within the case are observed and reconstructed in an abstract model. No comparisons with other experiences/cases are done. The analysis is based on 'chronologies,' a special form of time-series analysis; the chronological strategy aims to trace changes over time (Yin, 2003).

It must be noted that while the paper provided us with a broad range of insights from important stakeholders at Green Map System, I acknowledge several limitations. Firstly, the study extensively relied on first person viewpoints and expertise. Along with the limited sample size, and the context-dependent viewpoints espoused, the sample size used for this study was relatively small, thus restricting generalizability and core theory building. In order to counter this, I have provided rich empirical evidence of the process in action. Many of my interviewees' comments would be shaped by their own personal experience, with verification bias as an added concern. Despite this, the qualitative approach employed even for small sample sizes can "close in on real-life situations and test views directly in relation to phenomena as they unfold in practice." In meeting the criticisms of case study research, certain scholars have already demonstrated the potential of case studies as inspiration for new ideas (Siggelkow, 2007). I understand that in addressing the research question through the lens of a few organizations, generalizability could be perceived as an issue. In order to minimize potential for verification bias, I took steps to frame open-ended, non-directional questions to gain a richer, more holistic perspective from the respondents. In the future, I hope to conduct a larger study with a wider cross-section of observational data and interview subjects.

\section{GREEN MAP SYSTEM — CREATING SOCIAL PATHWAYS}

Founded in 1995 by eco-designer Wendy E. Brawer, Green Map System (GMS) Inc. is a US registered 501(c) (3) not-for-profit organization. It received independent non-profit status in 2000. Working with community leaders worldwide, GMS generates green maps that show points associated with sustainability in the broad categories of nature, culture, and society. Each of these green maps attempts to identify and highlight sites such as wetlands, wildlife habitats, safe drinking water, public parks and forests, bike lanes, community gardens, community foraging sites, and spaces for outdoor recreation in the local community. They also point out sites of significant social and cultural 
value such as museums, performance spaces, historical sites, and community centers, among others. Just as importantly, they also pinpoint areas of hazard such as landfills, brown fields, and pollution. The management at GMS believed that this user-centric approach to mapping would invigorate community driven initiatives: "Green Maps give people a fresh perspective on their own community by highlighting the emerging green economy, celebrating the uniqueness of home, including its biodiversity. Each Green Map is locally created and all share a lively universal iconography so residents and visitors can discover and get involved with farmers markets, community gardens, bike lanes and much more" (Wendy Brawer, Founding Director, Green Map System).

Each locally led green map project has a unique way of involving people of all ages in discussing, assessing, and highlighting green living resources as well as sites of natural, social, and cultural value. Involving youth, designers, social entrepreneurs, NGOs, universities, governmental and tourism agencies, these community-based green map projects attempt to build skills as they organize, design, and promote maps as well as interactive workshops and tours in cities, towns, and villages around the world. To spur inclusive participation, GMS empowers communities worldwide to chart their progress toward a sustainable future. In GMS's view, maps and mapmaking can help provide skills, resources, and overall awareness of possibilities for citizens to find ways to live more sustainably in their communities, by locating and shopping at a store that sells organic products, for example, or finding and eating at a restaurant that sources its kitchen with locally grown food.

By encouraging this process on a global scale, Green Map System strives to promote a sustainable global environment and a healthier climate, and help individuals discover their communities from a fresh perspective, engaging with local assets and issues and supporting green jobs and a low-carbon economy. With 65 countries involved since 1995, the synergistic strategy is 'Think Global, Map Local.' GMS partners with the creators of every locally led map, learning from their best practices and developing an adaptable suite of mapmaking resources to help each project determine the way forward in their own community and enable capacity building among the members of that community. Many of the projects develop an ongoing program that engages different sectors in creating diverse comprehensive, thematic, tourism-oriented, neighborhood and special purpose green maps.

In an effort to leverage the emergence of Web 2.0 technologies and social networking outlets in the early 21st century, GMS launched its own social mapping platform, the Open Green Map, in June 2009. The Open Green Map is a digital map informed by the public audience and it enables individuals worldwide to collaborate on mapmaking in a decentralized and efficient manner. Hubs in Indonesia, Japan, China, Cuba, Europe, and key mapmakers worldwide are vital collaborators. The movement has engaged and elevated the creativity, initiative, and devotion of a great diversity of youth, designers, social entrepreneurs, NGOs, universities, governmental and tourism agencies that have collectively published over 400 unique green maps and 125 Open Green Maps.

Each of the $500+$ published green maps helps bridge the gap between how community members and governmental agencies perceive community well-being and act on opportunities for social inclusion. Green mapmaking incubates new skills in critical assessment, collaborative project management, and communications for the emerging green economy. Utilizing social networking and an approach to media that is simultaneously local and global, Green Map System can alert more communities and decision-makers about the opportunities provided by green maps and the local impacts the organization has supported worldwide. The organization also provides tools and training for skill building and leadership through green mapmaking. The process of green mapping could be an effective educational tool where collaborative decision-making, project management, and production and community organizing skills are built.

As example, let us consider the 'Powerful Green Map of NYC.' Published in 2006, this was Green Apple Map's fifth edition and the 225th green map published by the worldwide green map movement. It was also the first to have energy use as its focus. The green map illustrated the city's energy footprint, with icons for energy impacts, conservation projects, and renewable resources.

GMS' maps vary immensely in terms of participants and purposes. Participants include NGOs, city agencies, social entrepreneurs, universities, CSR programs, local governments, community organizations, and youth groups. All hope to find practical solutions ways to fulfill their missions. Municipalities use green mapmaking to assist in land-use and environmental planning. For example, Washington, D.C. will soon publish printed and interactive green maps created by the District's Environment Office. At the same time, youth mapping effort at EL Haynes Public Charter School in the Columbia Heights and Petworth neighborhoods in Washington, D.C. is also getting underway.

GMS creates NYC's green map and works with partners throughout the city on the development of their own green maps or as contributors to the ones they publish. It is interesting to note that although GMS started as a local organization and then went global, they have very much kept the local component intact. 


\section{Green mapping in action}

An illustrative green map project is the 'Stop Global Warming' initiative in Thailand, which involves a partnership of Thai municipal staff and schoolchildren and started in 2005. In this project, the Thailand Environment Institute (TEI) works with local agencies at the municipal level aiming to increase awareness about climate change. The project emphasizes cooperation between local governments and schools, with students representing city residents. Participants provide ideas to improve their cities, such as bike lanes, public spaces, waste banks, recycling points, etc. This project encourages municipalities to work closely with schools and the community to initiate activities that reduce energy consumption and greenhouse gas emissions (Green Map Impacts, 2009). The project employs green mapmaking as a situation analysis tool to identify a city's 'strengths,' 'weaknesses,' 'opportunities,' and 'threats,' using GMS icons to visualize four main areas: waste minimization, sustainable transport, urban greening, and energy efficiency. The process of developing a green map involves community and youth groups through workshops organized by a municipality. Teams of students, teachers, and municipal staff are formed, and TEI workshops train adults and activate camp for youth. Thus far, TEI has introduced GMS to more than 60 Thai cities.

As a case in point, Tungsong, a city located in the south of Thailand, started its green map in 2005, charting green sites and pollution sites throughout the city. People of all ages participated. A year later, Tungsong developed the second version of the map using an aerial map as a base map, which shows all the physical characteristics of the city such as parks, roads, waterways, etc. Through the green map, environmental issues were prioritized and local action plans were developed to address traffic, solid waste management, increasing green area, flood prevention, and urban planning.

\section{Measures of success}

Mapping a wide breadth of sustainability relies on informal sources, local knowledge, and personal experience. Accordingly, it follows that the methods for measuring success will take a similar form. With a wide world of media formats that can display GMS' data in different ways to meet different audience needs, data sharing could also become a key indicator of success. The extent to which the green maps are being accessed and utilized by the public can be concretely measured through website traffic monitoring, fans and followers on social networking outlets such as Facebook and Twitter, and the dissemination of map information via widgets and other sharing resources. Another metric by which to measure success will include consideration of accolades, press coverage, and honors received by Green Map
System and locally led green map projects. The organization, its boards and network incorporate a method of continuous assessment of progress, participation, presentations, metrics, and revenue model institution. With its new online service section, green map also aims to encourage using its portfolio of resources and skills, all of which tend to promote healthy ecosystems, enterprises, and education, to enhance public understanding and opinion and to heighten impact. Reaching and engaging new sectors across the world, and transferring tools and replicable models, socially beneficial technology, experiential learning, and ecological literacy, are possible outcomes.

An additional method for measuring success considers temporality. Green maps have been continually published since 1995 . By observing the participating communities at periodic intervals, the level of impact each mapping project has had can be measured and evaluated to determine success. Such measurements might consist of analyzing the number of new businesses and non-profits created, changes in city infrastructure, acres of land preserved, and other trends. The following are two illustrative examples of green maps directly affecting the ecosystem of local communities worldwide:

(a) Yarmouth, Nova Scotia - The Yarmouth Green Map serves as an archetypal example of young stakeholders and important steps in the map-making process. The Yarmouth Green Map focuses on natural areas and spaces suitable for recreation. Data was collected using volunteered services from local students, who participated in fieldwork. The Yarmouth Green Map was instrumental in raising awareness of the area's recreational importance, which subsequently led to the preservation of Yarmouth's Broad Brook riparian zone.

(b) Kyoto Bicycle Route Map - In 2001, Green Map System directed the bicycle initiatives and ecotransportation of the Kyoto City Environmental Policy Department's 'Miyako Agenda 21 Forum.' The organization published the pocket-sized Kyoto Bicycle Route Map in the same year. This map suggested four cycling courses and hotels that support biking. The results of the released Bicycle Route Map were the Velo Taxi and one-coin bus service launched in Kyoto's central area. Moreover, KCTP, a rental bike delivering service, started as a result of this map's influence and received the annual grand prize of Kyoto venture business in 2002. Finally, the publication of the bicycle route map helped prompt the creation of Kyoto's light rail transit, which was implemented in 2005.

\section{DISCUSSION AND GOING FORWARD}

Regional green map hub leaders helped moderate and monitor the OGM and trained local mapmakers on how green mapmaking works and how to use its team management 
tools, as well as the adaptable youth, community, and locally designed map tools. GMS understood the need to have a steady income stream and a robust leadership network. In order to cultivate these social and business pathways, the organization had been considering potential partnerships with local agencies, universities, and non-profit organizations. The managers at GMS believed that creating local partnerships were key to fulfilling its mission-driven vision: "I'm interested in social and environmental projects and GMS has been complementing local leaders and their projects. The feeling and satisfaction to be helping others was the other motivation" (Carols Martinez, Latin American Liaison and Office Manager, Green Map System).

An important growth strategy the organization had determined was to create a process that included all stakeholders - from C-level executives to student interns - to collaborate during the development of a new map. Studies have shown that business and social impact can be attained through innovation processes that bring together lead users and relevant social groups (Battisti, 2012). The organization planned to use OGM data for sustainable development research activities and as a robust resource for entrepreneurs. As the organization grew in the size of the people involved, a key challenge was to professionalize the staff and related activities so they could continue their highimpact work in a sustainable manner: "The organization's evolution has been from a very community driven enterprise to a technology driven enterprise" (Dr. Robert W. Zuber, Organizational Consultant, Green Map System).

In terms of HR strategy, the company had evolved from an ad hoc network to a structure that included a board of directors, a finance committee, a technology group, and a group of international advisors. Development of the OGM platform included core technology partners from Colombia, the United Kingdom, United States, Japan, Romania, Finland, Israel, Indonesia, Sweden, and China, with numerous NGO partners, designers, and others. GMS also aimed to add a publicist (volunteer or intern) in the immediate future to extend its outreach across the United States.

One of the ongoing key goals for GMS to create social and business pathways was to work in collaboration with mapmakers and diverse user groups, including schools, religious congregations, environmental groups, and others, to share the maps and encourage more public interaction, and brainstorm ways on how best to invite contributions to, expand usage of, and innovate with the OGM social mapping platform in online, offline, and mobile formats. By engaging beneficiaries in such meaningful ways, social innovations can be more creatively and effectively developed and scaled for growth (Bhatt \& Altinay, 2013). As an extension of the network society, such technologies support the creation of new combinations - for example, by connecting previously disconnected actors. This may also spur self-organizing innovation processes via 'co-creation' as innovation is often recognized as an act of creative collaboration (Akehurst, Comeche \& Galindo, 2009). Sparking social entrepreneurs with diverse aims, GMS intended to draw out more of the successful local approaches with an ongoing green map project and apply them to the organization's revenue model as well as its adaptable mapmaking tools. As a possible growth strategy, GMS has created a services component and is in the process of offering consulting services to companies, schools, and universities, among other institutions.

Additionally, the company planned to add interfaces in multiple languages. The system supported French, German, Spanish, Portuguese, Dutch, Swedish, Japanese, Indonesian, and Chinese. More language interfaces were in the works. The organization aspired to incorporate new technologies and techniques on a continual basis in its effort to support communities worldwide. Although Brawer approached her organization's activities from both a socially oriented and a business approach, GMS overall still appeared to be primarily social-impact oriented in its goals.

The organization has become increasingly global, embraced new technologies, and incorporated new business approaches. As GMS expanded further into business-focused activities, Brawer had several fundamental challenges to deal with. For example, how could GMS maintain the community-oriented sense and grassroots image while making the necessary technological and business changes for growth in the future? Brawer and her team realized that it would be critical for GMS to succeed as a business while not losing sight of its overarching social goals. This apparent 'conflict' between social and business priorities is a central characteristic of social entrepreneurship. The tensions arise about the appropriate balance between serving locations and markets and varying prospects for generating earned income. The hybrid nature of the social enterprise leads to complex and difficult identity issues (Mulloth, 2011).

For the future research, the Green Map System example should be analyzed by using different perspectives with the aim of understanding its longer-term sustainability as an organization involved with creating systemic social change. 


\section{REFERENCES}

Adner, R. (2006). Match your innovation strategy to your innovation ecosystem. Harvard Business Review, 84(4), 98-107. Retrieved from https://hbr.org/2006/04/matchyour-innovation-strategy-to-your-innovation-ecosystem

Akehurst, G., Comeche, J. M., \& Galindo, M.A. (2009). Job satisfaction and commitment in the entrepreneurial SME. Small Business Economics, 32(3), 277-289. https://doi.org/10.1007/s11187-008-9116-Z

Alvord, S. H., Brown, L. D., \& Letts, C. W. (2004). Social entrepreneurship and societal transformation: An exploratory study. The Journal of Applied Behavioral Science, 40(3), 260-282. https://doi.org/10.1177/0021886304266847

Amabile, T. M., Patterson, C., Mueller, J., Wojcik, T., Odomirok, P. W., Marsh, M., \& Kramer, S. J. (2001). Academicpractitioner collaboration in management research: A case of cross-profession collaboration. Academy of Management Journal, 44(2), 418-431.https://doi.org/10.2307/3069464

Austin, J., Stevenson, H., \& Wei-Skillern, J. (2006). Social and commercial entrepreneurship: same, different, or both? Entrepreneurship Theory and Practice, 30(1),1-22. https://doi.org/10.1111/j.1540-6520.2006.00107.x

Battisti, S. (2012). Social innovation: The process development of knowledge-intensive companies. International Journal of Services Technology and Management, 18(3-4), 224-244. https://doi.org/10.1504/IJSTM.2012.052860

Beveridge, R., \& Guy, S. (2005). The rise of the ecopreneur and the messy world of environmental innovation. Local Environment, 10(6), 665-676. https://doi.org/10.1080/13549830500321972

Bhatt, P., \& Altinay, L. (2013). How social capital is leveraged in social innovations under resource constraints? Management Decision, 51(9), 1772-1792. https://doi.org/10.1108/MD-01-2013-0041

Bornstein, D. (2007). How to change the world: Social entrepreneurs and the power of new ideas. New York: Oxford University Press.

Burrell, G., \& Morgan, G. (1979). Sociological Paradigms and Organizational Analysis. Portsmouth: Heinemann.

Bygrave, W. D. (1989). The entrepreneurship paradigm (1): A philosophical look at its research methodologies. Entrepreneurship Theory and Practice, 14(1), 7-26. https://doi.org/10.1177/104225878901400102

Catford, J. (1998). Social entrepreneurs are vital for health promotion: But they need supportive environments too. Health Promotion International, 13(2), 95-97. https://doi.org/10.1093/heapro/13.2.95

Chesbrough, H. W. (2003). Open innovation: The new imperative for creating and profiting from technology. Brighton, MA: Harvard Business Press.
Choi, D. Y., \& Gray, E. R. (2008). Socially responsible entrepreneurs: What do they do to create and build their companies? Business Horizons, 51(4), 341-352. https://doi.org/10.1016/j.bushor.2008.02.010

Choi, N., \& Majumdar, S. (2014). Social entrepreneurship as an essentially contested concept: Opening a new avenue for systematic future research. Journal of Business Venturing, 29(3), 363-376. https://doi.org/10.1016/j.jbusvent.2013.05.001

Dean, T. J., \& McMullen, J. (2007). Toward a theory of sustainable entrepreneurship: Reducing environmental degradation through entrepreneurial action. Journal of Business Venturing, 22(1), 50-76. https://doi.org/10.1016/j.jbusvent.2005.09.003

Defourny, J., \& Nyssens, M. (2010). Conceptions of social enterprise and social entrepreneurship in Europe and the United States: Convergences and divergences. Journal of Social Entrepreneurship, 1(1), 32-53. https://doi.org/10.1080/19420670903442053

Drayton, W. (2010). Bill Drayton on the power of collaborative entrepreneurship in McKinsey's "What Matters? Retrieved from https://www.ashoka.org/en-us/story/bill-draytonpower-collaborative-entrepreneurship-mckinseys-what$\underline{\text { matters }}$

Eisenhardt, K. (1989). Building theories from case study research. Academy of Management Review, 14(4), 532-550. https://doi.org/10.2307/258557

Gioia, D. A., \& Pitre, E. (1990). Multiparadigm perspectives on theory building. Academy of Management Review, 15(4), 584-602. https://doi.org/10.2307/258683

Granovetter, M. S. (1973). The strength of weak ties. American Journal of Sociology, 78(6), 1360-1380. Retrieved from https://www.jstor.org/stable/2776392

Granovetter, M. (1983). The strength of weak ties: A network theory revisited. Sociological Theory, 1, 201-233. https://doi.org/10.2307/202051

Green Map Impacts. (2009). Green Map Impacts Book Project, 2009. Retrieved from https://www.greenmap.org/stories/ green-map-impacts $/ 220$

Grimes, M. G., McMullen, J. S., Vogus, T. J., \& Miller, T. L. (2013). Studying the origins of social entrepreneurship: Compassion and the role of embedded agency. Academy of Management Review, 38(3), 460-463. https://doi.org/10.5465/amr.2012.0429

Hart, S. L., \& Milstein, M. B. (2003). Creating sustainable value. Academy of Management Perspectives, 17(2), 56-67. https://doi.org/10.5465/ame.2003.10025194

Hagel, J., \& Brown, J. S. (2008). Creation nets: Harnessing the potential of open innovation. Journal of Service Science (JSS), 1(2), 27-40. https://doi.org/10.19030/jss.v1i2.4293 
Horwitch, M., \& Mulloth, B. (2010). The interlinking of entrepreneurs, grassroots movements, public policy and hubs of innovation: The rise of Cleantech in New York City. The Journal of High Technology Management Research, 21(1), 23-30. https://doi.org/10.1016/j.hitech.2010.02.004

Khavul, S., \& Bruton, G. D. (2013). Harnessing innovation for change: Sustainability and poverty in developing countries. Journal of Management Studies, 50(2), 285-306. https://doi.org/10.1111/j.1467-6486.2012.01067.x

Korosec, R. L., \& Berman, E. M. (2006). Municipal support for social entrepreneurship. Public Administration Review, 66(3), 448462. https://doi.org/10.1111/j.1540-6210.2006.00601.x

Kuckertz, A., \& Wagner, M. (2010). The influence of sustainability orientation on entrepreneurial intentions: Investigating the role of business experience. Journal of Business Venturing, 25(5), 524-539. https://doi.org/10.1016/j.jbusvent.2009.09.001

Lasprogata, G.A., \&Cotten,M.N.(2003).Contemplatingenterprise: The business and legal challenges of social entrepreneurship. American Business Law Journal, 41(1), 67-114. https://doi.org/10.1111/j.1744-1714.2003.tb00002.x

Leonard-Barton, D. (1990). A dual methodology for case studies: Synergistic use of a longitudinal single site with replicated multiple sites. Organization Science, 1(3), 248-266. https://doi.org/10.1287/orsc.1.3.248

Lettice, F., \& Parekh, M. (2010). The social innovation process: Themes, challenges and implications for practice. International Journal of Technology Management, 51(1), 139-158. Retrieved from http://www.inderscience.com/offer.php?id=33133

Lydon, M. (2003). Community mapping: The recovery (and discovery) of our common ground. Geomatica, 57(2), 131-144. Retrieved from http://mapping.uvic.ca/sites/ mapping.uvic.ca/files/lydon_cartographica_2003.pdf

MacGregor, S. P., \& Carleton, T. (2011). Sustaining innovation: Collaboration models for a complex world. New York: Springer.

Mair, J., \& Marti, I. (2006). Social entrepreneurship research: A source of explanation, prediction, and delight. Journal of World Business, 41(1), 36-44. https://doi.org/10.1016/j.jwb.2005.09.002

Makower, J. (1992). The map catalog: Every kind of map and chart on earth and even some above it (3rd ed). New York: Vintage.

Mulloth, B. (2011). Diversity in contemporary entrepreneurship: The evolution of two representative clean technology companies in New York City as cases in point (Doctoral dissertation). Polytechnic Institute of New York University, New York, United States.

Muniz, A. M. Jr., \& O'Guin, T. C. (2001). Brand Community. Journal of Consumer Research, 27(4), 412-432. https://doi.org/10.1086/319618

Munshi, N. V. (2010). Value creation, social innovation, and entrepreneurship in global economies. Journal of Asia-Pacific Business, 11(3), 160-165. https://doi.org/10.1080/10599231.2010.500569
Nicholls, A. (2006). Social entrepreneurship: New models of sustainable social change. New York: Oxford University Press.

Noruzi, M. R., Westover, J. H., \& Rahimi, G. R. (2010). An exploration of social entrepreneurship in the entrepreneurship era. Asian Social Science, 6(6), 3. https://doi.org/10.5539/ass.v6n6p3

Phills, J. A., Deiglmeier, K., \& Miller, D.T. (2008). Rediscovering social innovation. Stanford Social Innovation Review, 6(4), 34-43. Retrieved from https://ssir.org/articles/entry/ rediscovering social innovation

Porter, M. E., \& Kramer, M. R. (2011). The big idea: Creating shared value. How to reinvent capitalism: And unleash a wave of innovation and growth. Harvard Business Review, 89(1-2), 62-77. Retrieved from https://www.researchgate. net/publication/272576643 The Big Idea Creating Shared Value How to Reinvent Capitalism-and Unleash a Wave of Innovation and Growth

Seelos, C., \& Mair, J. (2005). Social entrepreneurship: Creating new business models to serve the poor. Business Horizons, 48(3), 241-246. https://doi.org/10.1016/j.bushor.2004.11.006

Shah, S. K., \& Corley, K. G. (2006). Building better theory by bridging the quantitative: Qualitative divide. Journal of Management Studies, 43(8), 1821-1835. https://doi.org/10.1111/j.1467-6486.2006.00662.x

Shaw, E., \& Bruin, A. de (2013). Reconsidering capitalism: the promise of social innovation and social entrepreneurship? International Small Business Journal, 31(7), 737-746. https://doi.org/10.1177\%2F0266242613497494

Shaw, E., \& Carter, S. (2007). Social entrepreneurship: Theoretical antecedents and empirical analysis of entrepreneurial processes and outcomes. Journal of Small Business and Enterprise Development, 14(3), 418-434. https://doi.org/10.1108/14626000710773529

Siggelkow, N. (2007). Persuasion with case studies. Academy of Management Journal, 50(1), 20-24. https://doi.org/10.5465/amj.2007.24160882

Thake, S., \& Zadek, S. (1997). Practical people, noble causes: How to support community-based social entrepreneurs. London: New Economics Foundation.

Vasi, I. B., \& King, B. G. (2012). Social movements, risk perceptions, and economic outcomes the effect of primary and secondary stakeholder activism on firms'perceived environmental risk and financial performance. American Sociological Review, 77(4), 573596. https://doi.org/10.1177\%2F0003122412448796

Von Hippel, E. (2006). Democratizing innovation. Cambridge: MIT Press.

Yin, R. (2003). Case-study research design \& methods. California: Sage.

Zahra, S. A., Gedajlovic, E., Neubaum, D. O., \& Shulman, J. M. (2009). A typology of social entrepreneurs: Motives, search processes and ethical challenges. Journal of Business Venturing, 24(5), 519-532. https://doi.org/10.1016/j.jbusvent.2008.04.007 


\section{Authorship}

\section{Balashankar Mulloth*}

University of Virginia, Frank Batten School of Leadership and Public Policy

235 McCormick Road, Charlottesville, Virginia, 22903-1738, United States.

E-mail address: mulloth@virginia.edu

(1) https://orcid.org/0000-0003-1360-6741

* Corresponding Author

\section{Funding}

There are no funders to report for this article.

\section{Conflict of Interests}

The authors have stated that there is no conflict of interest.

\section{Plagiarism Check}

The RAC maintains the practice of submitting all documents approved for publication to the plagiarism check, using specific tools, e.g.: iThenticate.

\section{Copyrights}

RAC owns the copyright to this content.

\section{Author's Contributions}

$1^{\text {st }}$ author: conceptualization (equal); data curation (equal); formal analysis (equal); investigation (equal); methodology (equal); project administration (equal); validation (equal); writing-original draft (equal); writing-review \& editing (equal).

\section{Peer Review Method}

This content was evaluated using the double-blind peer review process. The disclosure of the reviewers' information on the first page, as well as the Peer Review Report, is made only after concluding the evaluation process, and with the voluntary consent of the respective reviewers and authors.

\section{Data Availability}

The author chose not to share his database, and claim that he does so in view of the fact that as it was not mandatory to share the article in the open database, he chose not to share it as he is unclear on its impact.

RAC encourages data sharing but, in compliance with ethical principles, it does not demand the disclosure of any means of identifying research subjects, preserving the privacy of research subjects. The practice of open data is to enable the reproducibility of results, and to ensure the unrestricted transparency of the results of the published research, without requiring the identity of research subjects. 